\title{
PENGARUH HEALTH CONSCIOUSNESS TERHADAP PSYCHOLOGICAL WELLBEING YANG DIMEDIASI SIKAP OLAHRAGA PADA ORANG YANG OBESITAS DI BANDUNG RAYA
}

\author{
Pritha Dewi Indriyani, Sri Maslihah, Anastasia Wulandari
}

Departemen Psikologi Universitas Pendidikan Indonesia

J1. Dr. Setiabudi No.229, Isola, Kec. Sukasari, Kota Bandung, Jawa Barat 40154

Email: prithadewiind@gmail.com,smaslihah@gmail.com,diangem2@gmail.com

\begin{abstract}
ABSTRAK. Penelitian ini memiliki tujuan untuk melihat pengaruh dari health consciousness terhadap psychological wellbeing yang dimediasi perilaku olahraga pada orang yang obesitas di Bandung raya. Partisipan mengisi kuesioner yang berisi instrumen Sikap Olahraga untuk mengetahui tentang caranya menyikapi olahraga; dan Health Consciousness Scale untuk mengukur tingkat kesadaran untuk menjaga kesehatannya, dan Six Dimensions of Psychological Wellbeing Scale untuk mengukur tingkat kesejahteraan psikologis yang dimiliki. Teknik analisis data yang digunakan adalah Causal Analysis Mediation. Hasil yang diperoleh menunjukkan tingkat health consciousness dapat memengaruhi tingkat psychological wellbeing dengan kontribusi peningkatan sebesar 13,1\% ( $\mathrm{p}<0,001)$. Sikap olahraga ditemukan berfungsi sebagai mediator dengan kategori partial mediation yang artinya ketika ada variabel olahraga akan menurunkan koefisien regresi pengaruh health consciousness terhadap psychological wellbeing dibandingkan ketika hubungan langsung tanpa variabel olahraga. Sehingga dapat disimpulkan bahwa ketika responden sadar harus meningkatkan kesehatannya maka dia akan memiliki tingkat kesejahteraan psikologis yang tinggi dengan sikap olahraga yang positif.
\end{abstract}

Kata kunci: obesitas; health consciousness; psychological wellbeing; sikap olahraga

\section{INFLUENCES OF HEALTH CONSCIOUSNESS ON PSYCHOLOGICAL WELL BEING MEDIATED BY ATTITUDE OF EXCERCISE TOWARDS OBESE PERSONS}

\begin{abstract}
The aim of this study was to find out the effect of health consciousness on psychological wellbeing mediated by exercise attitude on people with obesity in Bandung Raya. Participants filled out a questionnaire that contained the instruments Sikap Olahraga to measure responden attitudes to exercise; and the Health Consciousness Scale to measure health consciousness levels, and Six Dimensions of Psychological Wellbeing Scale to measure the level of psychological wellbeing. Analyses using Causal Mediation Analysis revealed the results obtained indicate the level of health consciousness can affect the level of psychological wellbeing with an increase in contribution of 13,1\% ( $<<0,001)$. The study also found that effect of health consciousness on psychological wellbeing was partially mediated by exercise attitude which means that when respondents already health conscious then they'll have a high level of psychological wellbeing with positive attitude of exercise.
\end{abstract}

Keywords: obesity; health consciousness; psychological wellbeing; exercise attitude

\section{PENDAHULUAN}

Obesitas adalah ketika seseorang memiliki indeks massa tubuh lebih dari 25,0 kg/m2 akibat adanya penumpukan lemak di dalam tubuhnya (Dinas Kesehatan Provinsi Jawa Barat, 2016). Menurut data WHO (2017) bahwa kelebihan berat badan atau obesitas sudah menjadi prediktor tingkat kematian yang mencapai 2,8 juta orang setiap tahun. Profil kesehatan Jawa Barat (2016) menyebutkan telah tercatat dari hasil pemeriksaan sekitar 138.965 jiwa masyarakat Jawa Barat mengalami obesitas. Daerah Bandung Raya sebagai bagian dari Jawa Barat yang mencakup Kota Bandung; Kabupaten Bandung; Kabupaten Bandung Barat; Jatinangor/ Tamansari; dan Kota Cimahi memiliki sebagian besar wilayah perkotaan. Gaya hidup modern di wilayah perkotaan menjadikan makanan cepat saji yang berisiko tinggi dalam peningkatan obesitas lebih mudah didapatkan (Nurcahyo, 2011). Selain itu Nurcahyo (2011) juga mengatakan bahwa gaya hidup perkotaan yang lebih maju menjurus pada penurunan aktivitas fisik sehingga menyebabkan penumpukan lemak di dalam tubuh penyebab obesitas tersebut.
Dampak yang akan terjadi jika lemak di dalam tubuh menumpuk menyebabkan obesitas dan bisa membuat orang yang mengalaminya memiliki kemungkinan besar terkena masalah kesehatan (Obesity Working Group, 2011). Masalah kesehatan yang bisa terjadi diantaranya penyakit kardiovaskuler; diabetes mellitus; penyakit ginjal; kanker; dan gangguan masalah otot (The GBD 2015 Obesity Collaborators, 2017). Gangguan-gangguan tersebut merupakan jenis penyakit yang bisa mengarah langsung pada mortalitas atau kematian (Purwandari, 2014). Selain itu, obesitas juga berhubungan dengan kondisi psikologis penderitanya ketika sering diperlakukan negatif oleh orang-orang di sekitarnya melalui serangan verbal ataupun fisik dengan cara dipermalukan atau diasingkan karena orang obesitas dianggap malas; bodoh; dan kurang memiliki kekuatan untuk mengendalikan asupan makanan (Uzogara, 2017). Masih berkembang dalam pandangan masyarakat bahwa orang dengan kelebihan berat badan memiliki karakteristik tidak lincah; mudah lelah; dan cepat mengantuk (Nurcahyo, 2011). Akhirnya orang dengan obesitas akan mengalami ketidakpuasan terhadap bentuk tubuhnya sehingga berpengaruh terhadap peningkatan depresi; penurunan penerimaan diri; serta lemahnya 
kepuasan hidup dan harga diri seseorang (Uzogara, 2017).

Ketika orang dengan obesitas dianggap terlalu malas untuk bergerak justru dalam penelitian yang dilakukan oleh Maghvira (2016) menyebutkan bahwa pada akhirnya saat seseorang sudah terlanjur obesitas dan konsep dirinya mengarahkan untuk melakukan suatu tindakan atas tubuhnya maka orang obesitas tersebut mau berolahraga yang bukan hanya sekedar untuk menurunkan berat badan melainkan juga untuk menjaga kesehatannya. Konsep diri ini terkait dengan pemahaman tentang dirinya yang timbul akibat interaksi dengan orang lain dan kemudian muncul harapan atau cita-cita tentang diri (self-ideal); pembayangan tentang diri serta penentuan akan tingkah laku diri berikutnya (self-image); dan tindakan untuk menyukai diri sendiri serta berpikir-merasa-bertingkah laku sesuai dengan perasaan diri (self-esteem) (Maghvira, 2016).

Wood dan Shukla (2016) mengatakan bahwa ketika individu sadar terhadap masalah kesehatan yang akan menyerang terkait berat badannya, maka ada kecenderungan individu tersebut akan melakukan tindakan yang bisa mencegah terjadinya penyakit. Upaya preventif terhadap terjadinya suatu penyakit setelah mengetahui informasi tentang kesehatan dinamakan health consciousness (Hong, 2009). Amanda dan Sadida (2018) menyimpulkan health consciousness sebagai penilaian individu terhadap kesehatannya serta keterlibatan individu dalam menjaga kesehatannya, seperti menjalankan gaya hidup sehat dan mencari serta menggunakan informasi tentang kesehatan. Jadi, health consciousness bukan sekedar perwujudan dari kesadaran saja melainkan sudah terbentuk menjadi sebuah tindakan. Selain itu, Hassen dan Kibret (2016) memperjelas makna konsep kesehatan juga termasuk fokus pada aspek positif seperti kualitas hidup, kesehatan manusia, dan kesejahteraan psikologis. Sehingga seseorang yang health conscious bukan hanya akan bertindak untuk meningkatkan kesehatan fisiknya saja melainkan juga kesehatan mentalnya termasuk kesejahteraan psikologisnya. Karn dan Swain (2017) mengatakan bahwa orang yang health conscious lebih berpikir untuk hidup dengan baik; berolahraga atau beraktivitas fisik yang cukup; dan juga merawat kesehatannya yang pada akhirnya akan membentuk kesehatan psikologis (psychological wellness). Sedangkan, kesehatan (wellness) merupakan proses seumur hidup seseorang untuk meningkatkan kualitas hidup sehingga terjaga keseimbangan pikiran; tubuh; dan jiwa dan secara positif mengembangkan kesehatan fisik; emosional; sosial; kesejahteraan psikologis (psychological wellbeing) (Karn dan Swain, 2017).

Ketika muncul kesadaran untuk melakukan suatu tindakan yang bermanfaat bagi kesehatannya saat mengetahui tentang dampak obesitas yang negatif bagi kondisi fisik dan psikisnya akan membuatnya lebih termotivasi untuk melakukan intervensi penurunan berat badan (Wood dan Shukla, 2016). Salah satu cara untuk menurunkan berat badan adalah dengan berolahraga. Dapat dikatakan bahwa salah satu motif seseorang yang obesitas bisa terdorong untuk menurunkan berat badannya adalah jika mengetahui dan menyadari bahwa obesitas akan berdampak buruk bagi kesehatan maupun penampilannya. Bagi orang dengan obesitas, olahraga merupakan aktivitas yang perlu dilakukan karena memegang peranan penting untuk membantu mengurangi dampak negatif obesitas (Nurcahyo, 2011).

Informasi mengenai pentingnya olahraga bisa menjadi dasar pengetahuan bagi seseorang yang obesitas sehingga orang tersebut akan bersikap positif yang pada akhirnya diwujudkan dalam suatu tindakan yang bisa diamati oleh indera yaitu melakukan olahraga (Tandayu, 2014). Seseorang yang rutin mengikuti olahraga selain akan mencapai kesejahteraan secara fisik juga akan berpengaruh terhadap pengoptimalan brain-derived neurotrophic factor (BDNF) yang berkaitan dengan peningkatan fungsi kognitif maupun emosional yang juga meningkat (Archer dan Garcia, 2014a). Olahraga juga menjadi salah satu cara bagi seseorang yang obesitas untuk menanggulangi masalah secara psikologis akibat obesitas karena dengan berolahraga bisa meningkatkan hormon serotonin dan dopamin serta sekresi endorfin yang bisa meningkatkan kebahagiaan (Adiono et.al., 2018). Selain itu, pembentukan sikap yang positif dapat menggambarkan kebahagiaan karena aspek kognitif kebahagiaan meliputi evaluasi yang positif terhadap kehidupan dan aspek afektif kebahagiaan meliputi rasa kesejahteraan, yaitu kesejahteraan psikologis (Venhoven, 2006).

Berdasarkan penjelasan di atas, jika tingkat kesadaran akan pentingnya kesehatan (health consciousness) tinggi maka seseorang akan berusaha melakukan tindakan yang bisa memengaruhi kesehatannya salah satunya adalah dengan berolahraga, semakin positif dampak yang dirasakan dari berolahraga akan memengaruhi pandangan seseorang dengan olahraga sehingga membentuk sikap olahraga yang positif. Begitupun ketika sikap terhadap olahraga semakin positif maka ada kecenderungan psychological wellbeing meningkat karena dengan sikap yang positif maka semakin menggambarkan kebahagiaan terkait evaluasi kognitif dan afektif pada kebahagiaan adalah menyangkut kesejahteraan psikologis. Peneliti tertarik untuk mencari tahu fungsi mediator dari sikap olahraga dalam menjembatani pengaruh health consciousness terhadap psychological wellbeing. Peranan variabel mediator terdiri dari dua jenis yaitu peranan langsung (direct effect) dan peranan tidak langsung (indirect effect). Menurut Baron dan Kenny (1986), secara umum sebuah variabel merupakan mediator yang efektif ketika dalam peranan total, porsi jalur peranan tidak langsung lebih besar dibanding dengan peranan secara langsung. 

Bandung Raya

Selain itu peranan tidak langsung tersebut diharapkan signifikan secara statistik.

\section{METODE}

Pendekatan yang digunakan dalam penelitian ini adalah deskriptif kuantitatif (Creswell, 2009). Untuk menguji hipotesis utama dalam penelitian akan menggunakan model penelitian mediasi untuk menguji apakah terdapat peranan variabel mediator $(Z)$ dalam memediasi pengaruh variabel independen $(\mathrm{X})$ terhadap variabel dependen (Y) (Jose, 2013).

Hipotesis utama $(\mathrm{H})$ dalam penelitian ini adalah sikap olahraga $(\mathrm{Z})$ menjadi mediator secara signifikan atas pengaruh health consciousness (X) terhadap psychological wellbeing (Y) pada orang yang obesitas di Bandung Raya. Selain itu, penelitian ini juga memiliki subhipotesis diantaranya yaitu:

Subhipotesis 1 : terdapat pengaruh health consciousness (X) terhadap psychological wellbeing (Y) pada orang yang obesitas di Bandung Raya;

Subhipotesis 2 : terdapat pengaruh health consciousness $(\mathrm{X})$ terhadap sikap olahraga $(\mathrm{Z})$ pada orang yang obesitas di Bandung Raya;

Subhipotesis 3 : terdapat pengaruh sikap olahraga (Z) terhadap psychological wellbeing (Y) pada orang yang obesitas di Bandung Raya

$\mathrm{H}$ dianalisis dengan Causal Mediation Analysis, sedangkan Subhipotesis 1; Subhipotesis 2; dan Subhipotesis 3 diuji dengan analisis regresi sederhana.

Jumlah populasi orang obesitas di Bandung Raya yang meliputi Kota Bandung; Kota Cimahi; sebagian Kabupaten Bandung; sebagian Kabupaten Bandung Barat; dan sebagian Kabupaten Sumedang (Pemprov Jawa Barat, 2013) tidak bisa dipastikan sehingga peneliti menentukan jumlah subjek yang ditargetkan adalah minimal 124 orang (Cohen dan Cohen dalam Varvoonhis dan Morgan, 2007). Hal tersebut merupakan rules of thumb untuk perhitungan regresi dengan satu dependent variable. Partisipan yang terlibat dalam penelitian ini memiliki karakteristik yaitu bertubuh gemuk dan atau memiliki indeks massa tubuh $\geq 25,0 \mathrm{~kg} / \mathrm{m} 2$ yang diukur menggunakan rumus:

\section{IMT $=\quad$ Berat Badan $(\mathbf{k g})$ (Tinggi Badan (meter) $)^{2}$}

Untuk mengukur sikap olahraga pada sampel akan digunakan Skala Sikap terhadap Olahraga yang dibuat sendiri oleh peneliti dengan menyesuaikan tiap item berdasarkan dimensi sikap yaitu kognitif; afektif; dan konatif yang dipaparkan oleh Ajzen (1993); Zuchdi (1995); Notoatmodjo (dalam Rusmanto, 2013) serta dilengkapi pernyataan tentang respon subjek terhadap olahraga serta pilihan jawaban berupa skala likert $1=$ Sangat tidak setuju; $2=$ Tidak setuju; $3=$ Setuju; $4=$
Sangat setuju. Item yang dibuat oleh peneliti menurut setiap dimensi contohnya pada dimensi kognitif adalah "Berjalan kaki bisa membuat jantung; paru-paru dan otot lebih sehat serta sistem sirkulasi darah lancar", pada dimensi afektif contohnya "Saya senang melakukan olahraga", pada dimensi konatif contohnya "Saya melakukan olahraga minimal sekali dalam seminggu".

Adapun instrumen yang digunakan dalam mengukur health consciousness ini menggunakan Health Consciousness Scale (HCS) yang diadaptasi dari penelitian yang dilakukan oleh Hong (2009) berdasarkan lima dimensi yang dijabarkan oleh penelitian-penelitian sebelumnya oleh Kraft dan Goodell, 1993; Jayanti dan Burns, 1998; Michaelidou dan Hassan, 2008; Dutta-Bergman, 2004a, 2004b, 2005, 2006, 2007; Furnham \& Forey, 1994; Tai dan Tam, 1997 dengan reliabilitas sebesar 0,85 . Instrumen yang akan diberikan pada penelitian in akan disesuaikan dengan kebutuhan data yang ingin diketahui dari sampel. Terdapat tujuh skala likert yang digunakan untuk mengukur instrumen ini, yaitu 1 (Sangat Tidak Setuju); 2 (Tidak Setuju); 3 (Cenderung Tidak Setuju); 4 (Netral); 5 (Cenderung Setuju); 6 (Setuju); dan 7 (Sangat Setuju).

Instrumen untuk variabel kesejahteraan psikologis ini dibuat berdasarkan six dimensions of Psychological Wellbeing Scale oleh Ryff yang memiliki reliabilitas sebesar 0,86 dan disesuaikan dengan kebutuhan data yang ingin diketahui dari sampel penelitian yang akan dilakukan oleh peneliti. Instrumen akan diberikan secara acak semua kepada sampel. Kemudian terdapat 7 skala Likert yang digunakan untuk mengukur instrumen ini, yaitu 1 (Sangat Tidak Setuju); 2 (Tidak Setuju); 3 (Cenderung Tidak Setuju); 4 (Netral); 5 (Cenderung Setuju); 6 (Setuju); dan 7 (Sangat Setuju).

Alat ukur pada penelitian ini telah diuji cobakan pada 140 responden baik laki-laki maupun perempuan dengan rentang usia 18 tahun hingga 40 tahun. Alat ukur Sikap Olahraga memiliki reliabilitas sebesar 0,90 atau reliabel dengan skor reliabilitas item sebesar 0,98 atau sangat reliabel dan skor reliabilitas person sebesar 0,92 atau sangat reliabel.

Alat ukur Health Consciousness memiliki skor reliabilitas sebesar 0,89 atau reliabel dengan skor reliabilitas item sebesar 0,98 atau sangat reliabel dan skor reliabilitas person sebesar 0,91 atau sangat reliabel.

Alat ukur six dimensions of Psychological Wellbeing Scale memiliki skor reliabilitas sebesar 0,87 atau reliabel dengan skor reliabilitas item sebesar 0,98 atau sangat reliabel dan skor reliabilitas person sebesar 0,88 atau reliabel.

\section{HASIL DAN PEMBAHASAN}

Pada bab ini dipaparkan mengenai analisis dari data yang diperoleh 125 responden selama bulan April 2019. 
Hasil analisis data yang diuraikan antara lain gambaran secara demografis dan kategorisasi pada tiga variabel penelitian: sikap olahraga; health consciousness; dan psychological wellbeing, serta analisis statistik untuk menjawab pertanyaan penelitian dikaitkan dengan landasan teori.

Gambaran karakteristik responden secara demografis diperoleh dari data yang terletak pada formulir isian mengenai data diri ketika proses pengambilan data. Data demografis yang diambil adalah jenis kelamin; status pernikahan; pekerjaan/ kegiatan sehari-hari; kondisi kesehatan; dan aktivitas olahraga. Data tersebut dapat dilihat dalam tabel berikut:

Tabel 4.1 Data Demografis Responden

\begin{tabular}{|c|c|c|c|}
\hline $\begin{array}{l}\text { Status De- } \\
\text { mografis }\end{array}$ & $\begin{array}{c}\text { Data Respon- } \\
\text { den }\end{array}$ & Frekuensi & $\%$ \\
\hline \multirow[t]{2}{*}{$\begin{array}{c}\text { Jenis Ke- } \\
\text { lamin }\end{array}$} & Perempuan & 74 & 59,2 \\
\hline & Laki-laki & 51 & 40,8 \\
\hline \multirow[t]{3}{*}{ Status } & Belum Menikah & 108 & 86,4 \\
\hline & Menikah & 16 & 12,8 \\
\hline & Cerai & 1 & 0,8 \\
\hline \multirow[t]{10}{*}{$\begin{array}{l}\text { Pekerjaan/ } \\
\text { Kegiatan } \\
\text { Sehari-hari }\end{array}$} & $\begin{array}{c}\text { Karyawan/ } \\
\text { Pegawai }\end{array}$ & 21 & 16,8 \\
\hline & $\begin{array}{l}\text { Freelancer/Ma- } \\
\text { gang }\end{array}$ & 6 & 4,8 \\
\hline & Social Worker & 1 & 0,8 \\
\hline & Pimpinan & 4 & 3,2 \\
\hline & Wirausahawan & 4 & 3,2 \\
\hline & Pengajar & 13 & 10,4 \\
\hline & $\begin{array}{l}\text { Pelajar/ Maha- } \\
\text { siswa }\end{array}$ & 64 & 51,2 \\
\hline & $\begin{array}{l}\text { Pengangguran/ } \\
\text { Pegiat refresh- } \\
\text { ing(membaha- } \\
\text { giakan diri) }\end{array}$ & 6 & 4,8 \\
\hline & IRT & 3 & 2,4 \\
\hline & Olahraga & 3 & 2,4 \\
\hline \multirow[t]{2}{*}{$\begin{array}{c}\text { Kondisi } \\
\text { Kesehatan }\end{array}$} & Sehat & 84 & 67,2 \\
\hline & Sakit & 41 & 32,8 \\
\hline \multirow[t]{2}{*}{ Olahraga } & $\mathrm{Ya}$ & 98 & 78,4 \\
\hline & Tidak & 27 & 21,6 \\
\hline
\end{tabular}

Dari tabel 4.1 dipaparkan bahwa jumlah responden terbanyak merupakan perempuan sejumlah 59,2\%. Menurut data tersebut juga terlihat bahwa lebih banyak responden yang berstatus belum menikah dengan jumlah 86,4\%. Responden dengan pekerjaan/ kegiatan sehari-hari sebagai mahasiswa/ pelajar berjumlah lebih banyak yaitu 51,2\%. Selain itu, responden juga lebih banyak yang mengaku sehat sebanyak $67,2 \%$. Berdasarkan aktivitas olahraga yang dilakukan, 78,4\% responden mengaku suka berolahraga.

\section{Pengaruh Health Consciousness Terhadap Psychological Wellbeing}

Subhipotesis 1 memiliki hipotesis statistik sebagai berikut:

$\mathrm{H}_{\mathrm{o}}$ : Health consciousness $(\mathrm{X})$ tidak berpengaruh secara signifikan terhadap variabel psychological wellbeing $(\mathrm{Y})$.

$\mathrm{H}_{1}$ : Health consciousness $(\mathrm{X})$ berpengaruh secara signifikan terhadap variabel psychological wellbeing $(\mathrm{Y})$.

Perhitungan uji regresi dilakukan dengan menggunakan aplikasi JASP. Hasil uji regresi ini dapat dilihat dalam tabel berikut:

Tabel 4. 2 Hasil Pengujian Pengaruh Health Consciousness (X) terhadap Psychological Wellbeing (Y)

\begin{tabular}{|c|c|c|c|}
\hline Variabel & $\begin{array}{c}\text { Ko e fi si i n } \\
\text { Regresi }\end{array}$ & Sig. & Adj. R $^{2}$ \\
\hline $\begin{array}{c}\text { Health Con- } \\
\text { sciousness }\end{array}$ & 0,227 & 0,001 & $13,1 \%$ \\
\hline
\end{tabular}

Nilai signifikansi sebesar 0,001 $(\mathrm{p}<0,05)$ yang berarti bahwa health consciousness mempengaruhi psychological wellbeing orang yang obesitas di Bandung Raya. Setiapkenaikanskorhealth consciousness (X)maka akan meningkatkan skor psychological wellbeing (Y) sebesar 0,227. Pengaruh langsung health consciousness terhadap psychological wellbeing dengan presentase $13,1 \%(\mathrm{p}<0.001)$, artinya kemungkinan adanya faktor lain yang memengaruhi tingkat kesejahteraan psikologis pada subjek sangat besar mengingat angka 13,1\% masih terlalu kecil. Jika menurut Karn dan Swain (2017) bahwa orang yang sadar tentang masalah kesehatannya (health conscious) akan berupaya meningkatkan kualitas kesehatan diri secara fisik maupun psikologis hingga mampu mencapai wellness dimana psychological wellbeing sebagai salah satu bagiannya, maka bisa dikatakan penelitian ini sesuai. Namun, kita masih perlu menemukan $86,9 \%$ faktor lain yang bisa meningkatkan psychological wellbeing selain dari faktor pengaruh health consciousness, karena bisa jadi kesejahteraan psikologis yang diperoleh subjek bukan hanya sekedar karena subjek sadar harus sehat saja melainkan perlu ada intervensi lain.

\section{Pengaruh Health Consciousness Terhadap Sikap Olahraga}

Subhipotesis 2 memiliki hipotesis statistik sebagai berikut:

$\mathrm{H}_{\mathrm{o}}$ : Health consciousness $(\mathrm{X})$ tidak berpengaruh secara signifikan terhadap variabel sikap olahraga (Z).

$\mathrm{H}_{1}$ : Health consciousness $(\mathrm{X})$ berpengaruh secara 
signifikan terhadap variabel sikap olahraga $(\mathrm{Z})$.

Perhitungan uji regresi dilakukan dengan menggunakan aplikasi JASP. Hasil penghitungan uji regresi ini dapat dilihat dalam tabel berikut:

Tabel 4. 3 Hasil Pengujian Pengaruh Health Consciousness (X) terhadap Sikap Olahraga (Z)

\begin{tabular}{|c|c|c|c|}
\hline Variabel & $\begin{array}{c}\text { Koefisien } \\
\text { korelasi }\end{array}$ & Sig. & Adj. R ${ }^{2}$ \\
\hline $\begin{array}{c}\text { Health Con- } \\
\text { sciousness }\end{array}$ & 0,394 & 0,001 & $29,1 \%$ \\
\hline
\end{tabular}

Nilai signifikansi sebesar $0,001 \quad(\mathrm{p}<0,05)$ yang berarti bahwa health consciouness mempengaruhi besarnya sikap olahraga orang yang obesitas di Bandung Raya. Setiap kenaikan skor health consciousness (X) maka akan meningkatkan skor sikap olahraga (Z) sebesar 0,394. Hasil ini mendukung penelitian DiPietro; Remar; dan Parsa (2016) bahwa health consciousness sebagai cara seseorang mencoba mencari tahu dan merespon informasi kesehatan yang diterima dengan cara sadar dan peduli akan kesehatan dan kesejahteraan pribadi mereka kemudian termotivasi untuk meningkatkan kesehatan dan kualitas hidup mereka. Ketika seseorang mengetthui informasi mengenai pentingnya olahraga bisa menjadi dasar pengetahuan bagi seseorang yang obesitas sehingga orang tersebut akan bersikap positif yang pada akhirnya diwujudkan dalam suatu tindakan yang bisa diamati oleh indera yaitu melakukan olahraga (Tandayu, 2014).

\section{Pengaruh Sikap Olahraga Terhadap Psychological Wellbeing}

Subhipotesis 3 memiliki hipotesis statistik sebagai berikut:

$\mathrm{H}_{\mathrm{o}}$ : Sikap olahraga $(\mathrm{Z})$ tidak berpengaruh secara signifikan terhadap variabel psychological wellbeing (Y).

$\mathrm{H}_{1}$ : Sikap olahraga $(\mathrm{Z})$ berpengaruh secara signifikan terhadap variabel psychological wellbeing $(\mathrm{Y})$.

Uji regresi variabel perilaku olahraga terhadap psychological wellbeing menggunakan aplikasi JASP menghasilkan data sebagai berikut:

Tabel 4. 4 Hasil Pengujian Pengaruh Sikap Olahraga (Z) terhadap Psychological Wellbeing (Y)

\begin{tabular}{|c|c|c|c|}
\hline Variabel & $\begin{array}{c}\text { Koefiien ko- } \\
\text { relasi }\end{array}$ & Sig. & Adj. $\mathrm{R}^{2}$ \\
\hline $\begin{array}{c}\text { Sikap Olah- } \\
\text { raga }\end{array}$ & 0,398 & 0,001 & $21,5 \%$ \\
\hline
\end{tabular}

Nilai signifikansi sebesar $0,001 \quad(p<0,05)$ yang berarti bahwa sikap olahraga mempengaruhi besarnya psychological wellbeing orang yang obesitas di Bandung Raya. Setiap kenaikan skor sikap olahraga (Z) maka akan menaikkan skor psychological wellbeing (Y) sebesar
0,398. Saat berolahraga dengan derajat usaha fisik dan energi yang dikeluarkan akan tersedia biomarker (tanda perubahan biologis) berupa peningkatan hormon serotonin dan dopamin serta sekresi endorfin yang bisa meningkatkan kebahagiaan sebagai faktor dasar untuk meningkatkan psychological wellbeing atau kesejahteraan psikologis (Weiss; Westerhof; Bohlmeijer, 2016; Adiono et.al., 2018). Informasi mengenai pentingnya olahraga bisa menjadi dasar pengetahuan bagi seseorang yang obesitas sehingga orang tersebut akan bersikap positif yang pada akhirnya diwujudkan dalam suatu tindakan yang bisa diamati oleh indera yaitu melakukan olahraga (Tandayu, 2014). Selain itu, pembentukan sikap yang positif dapat menggambarkan kebahagiaan karena aspek kognitif kebahagiaan meliputi evaluasi yang positif terhadap kehidupan dan aspek afektif kebahagiaan meliputi rasa kesejahteraan, yaitu kesejahteraan psikologis (Venhoven, 2006).

\section{Pengaruh Health Consciousness Terhadap Psychological Wellbeing yang Dimediasi Sikap Olahraga}

Hipotesis utama memiliki hipotesis statistik sebagai berikut:

$\mathrm{H}_{\mathrm{o}}$ :Sikap olahraga $(\mathrm{Z})$ tidak memediasi pengaruh health consciousness $(\mathrm{X})$ terhadap psychological wellbeing (Y).

$\mathrm{H}_{1}$ : Sikap olahraga $(\mathrm{Z})$ memediasi pengaruh health consciousness $(\mathrm{X})$ terhadap psychological wellbeing (Y).

Hasil dari causal mediation analysis dengan menggunakan aplikasi JASP dapat dilihat pada tabel berikut ini:

Tabel 4. 5 Hasil Pengujian Pengaruh Health Consciousness (X) terhadap Psychological Wellbeing (Y) yang Dimediasi oleh Sikap Olahraga $(Z)$

\begin{tabular}{|c|c|c|c|}
\hline Variabel & $\begin{array}{c}\text { Koefiien ko- } \\
\text { relasi }\end{array}$ & Sig. & Adj. $\mathrm{R}^{2}$ \\
\cline { 1 - 2 } $\begin{array}{c}\text { Health Con- } \\
\text { sciousness }\end{array}$ & 0,100 & 0,001 & $22,8 \%$ \\
\cline { 1 - 2 } $\begin{array}{c}\text { Sikap Olah- } \\
\text { raga }\end{array}$ & 0,323 & & \\
\hline
\end{tabular}

Besaran pengaruh health consciousness terhadap psychological wellbeing yang dimediasi oleh sikap olahraga pada orang yang obesitas di Bandung Raya dapat diketahui dengan melihat tabel di atas. Angka signifikansi sebesar 0,001 menunjukkan pengaruh yang signifikan. Health consciousness dengan kontribusi sikap olahraga sebagai variabel mediator memengaruhi psychological wellbeing sebesar 22,8\%. Setiap kenaikan skor health consciousness (X) maka akan menaikkan skor psychological wellbeing (Y) sebesar 0,100 dan setiap kenaikan skor sikap olahraga (Z) akan menaikkan skor psychological wellbeing (Y) sebesar 0,323. 
Ketika kehadiran variabel mediator (Z) menghilangkan pengaruh variabel independen ke variabel dependen, maka hal itu menunjukkan variabel mediator berfungsi dengan kategori full mediation, sedangkan jika pengaruh variabel independen ke dependen masih ada namun dengan penurunan koefisien regresi, maka variabel mediator berfungsi pada kategori partial mediation (Baron \& Kenny, 1986).

Pengaruh sikap olahraga ini sebagai variabel mediator mengurangi efektivitas pengaruh langsung health consciousness terhadap psychological wellbeing karena dalam penelitian Wood dan Shukla (2016) menunjukkan bahwa health consciousness bisa mendorong seseorang untuk melakukan aktivitas yang mengarah pada peningkatan kesehatan juga dalam hal kesejahteraan psikologis yaitu dengan olahraga. Sehingga dari penelitian ini bisa dikatakan bahwa ketika seseorang sadar harus meningkatkan kesehatannya maka dia akan memiliki tingkat kesejahteraan psikologis yang tinggi dengan sikap olahraga yang positif. Meskipun demikian, prosentase pengaruh mediasi yang hanya mencapai 22.8\% merupakan angka yang kecil sehingga masih ada kemungkinan faktor lain yang memengaruhi psychological wellbeing. Hal tersebut juga ditunjukkan pada data deskriptif tabel di bawah ini bahwa dimensi psychological wellbeing yang ternyata rata-ratanya lebih tinggi hanya pada dimensi personal growth, sedangkan dimensi yang lain masih memiliki nilai rata-rata lebih sedikit.

\section{Tabel 4. 6 Simpulan Sementara Data Deskriptif}

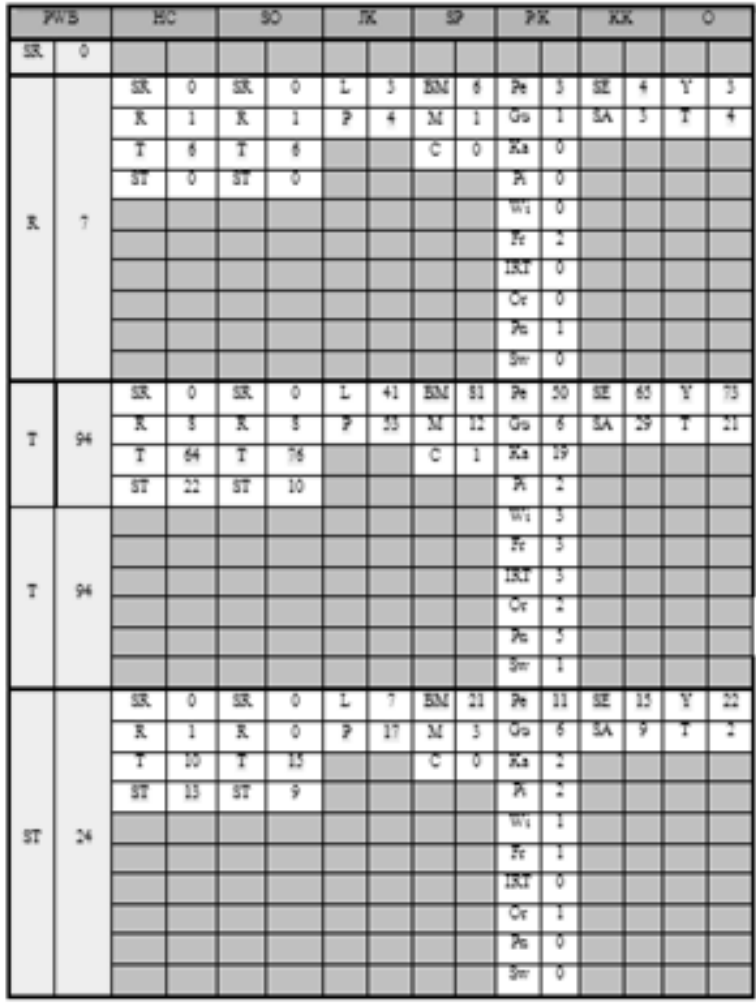

antara Iaın sebagaı perıкut:

1. Terdapat faktor lain yang bisa memengaruhi psychological wellbeing namun tidak menjadi bahasan dalam penelitian ini sehingga menyebabkan kurang efektifnya sikap olahraga sebagai variabel mediator.

2. Kriteria sampel masih kurang spesifik sehingga ada kemungkinan perbedaan karakteristik pada responden juga menyebabkan hasil pengaruh kurang efektif.

3. Penelitian ini hanya dilakukan di Kota Bandung sehingga peneliti tidak bisa langsung di generalisasikan di semua kota hasilnya akan sama.

\section{SIMPULAN}

Berdasarkan penelitian yang telah dilakukan mengenai pengaruh health consciousness terhadap psychological wellbeing yang dimediasi oleh perilaku olahraga pada orang yang obesitas di Bandung Raya, dapat disimpulkan bahwa perilaku olahraga memberikan kontribusi dalam memediasi pengaruh health consciousness terhadap psychological wellbeing. Artinya, sikap olahraga bisa menjadi jembatan pengaruh health consciousness terhadap psychological wellbeing.

Dalam penelitian ini terdapat hasil yang menyatakan bahwa ketika seseorang obesitas memiliki tingkat kesadaran yang tinggi terhadap masalah kesehatannya dan memiliki kecenderungan melakukan tindakan untuk mencegah penyakit (health consciousness) maka nilai kesejahteraan psikologis (psychological wellbeing) yang dia miliki juga tinggi. Namun ternyata health consciousness bukan satu-satunya faktor yang bisa memengaruhi peningkatan psychological wellbeing pada orang yang obesitas, sehingga sikap olahraga dimunculkan sebagai faktor lain yang juga bisa memengaruhi peningkatan psychological wellbeing. Setelah dilakukan uji regresi pada ketiga variabel menggunakan causal mediation analysis, hipotesis penelitian ini terbukti dan menyatakan bahwa tingkat kesejahteraan psikologis pada seseorang yang obesitas akan semakin meningkat jika dia sadar akan pentingnya kesehatan dan cenderung akan melakukan perilaku yang bisa mencegah penyakit sehingga memunculkan juga sikap yang positif terhadap olahraga. Pembentukan sikap yang positif ini karena sebelumnya orang dengan obesitas tersebut mengetahui bahwa olahraga merupakan salah satu perilaku preventif dalam mengatasi masalah penyakit khususnya obesitas.

\section{DAFTAR PUSTAKA}

Adiono, A. D., Bakhtiar, Y., Supatmo, Y., \& Muniroh, M. (2018). Perbandingan Efek Olahraga Indoor dan Outdoor, 7(2), 1088-1098.

Ajzen, I. (1993). Attitude theory and the attitude-behavior relation .

Albarracin, D., Sunderrajan, A., \& Lohmann, S. (2018). The Psychology of Attitudes, Motivation, and Persuasion ., (May). 
Allport, G. W. (1935). Attitudes. In C. Murchison (Ed.), Handbook of Social Psychology (pp. 798-844). Worcester, Mass.: Clark University Press.

Amanda, R., \& Sadida, N. (2018). Hubungan antara Health Consciousness dengan Employee WellBeing pada Karyawan di DKI Jakarta. Jurnal Psikologi Sains Dan Profesi, 2(3), 216-221.

Archer, T., \& Garcia, D. (2014a). Physical Exercise Improves Cognition and Health in ADHD. Journal of Novel Physiotherapies, 4(3). https://doi. org/10.4172/2165-7025.1000208

Archer, T., \& Garcia, D. (2014b). Physical Exercise Influences Academic Performance and Well-being in Children and Adolescents, 1(1), 1-3. https://doi. org/10.4172/1234-3425.1000e102

Arli, D., \& Sutanto, N. (2017). Investigating the Importance of Sediment Resuspension in Alexandrium. John Wiley \& Sons, Ltd., 1-10.

Auguntari, I. T., Ray, H. R. D., \& Nuryadi. (2018). Aktivitas Fisik High Intensity Intermittent Exercise (HIIE) : Antara Obesitas dan Self-Esteem. Jurnal Pendidikan Jasmani Dan Olahraga, 3(1), 1-9.

Ayu, R., \& Sartika, D. (2011). Faktor Risiko Obesitas pada Anak 5-15 Tahun di Indonesia, 15(1), 37-43.

Azwar, Saifudin (1988). Sikap Manusia. Yogyakarta: LibertyBaron, R. M., \& Kenny, D. a. (1986). The Moderator-Mediator Variable Distinction in Social The Moderator-Mediator Variable Distinction in Social Psychological Research: Conceptual, Strategic, and Statistical Considerations. Journal of Personality and Social Psychology, 51(6), 1173-1182. https://doi.org/10.1037/00223514.51.6.1173

Badan Penelitian dan Pengembangan Kesehatan Departemen Kesehatan RI (2009). RISET KESEHATAN DASAR ( RISKESDAS ) PROVINSI JAWA BARAT TAHUN 2007.

Biddle and Nigg. (2016). Theories of Exercise Behavior. International Journal of Sport Psychology, 2000(31), 290-304.

Compton, W.C. (2005). Introduction to Positive Psychology. .United States of America: Thopmson Wadsworth.

Creswell, J.W. (2009). Research design. Third edition. Yogyakarta: Pustaka Pelajar

Departemen Kesehatan. (2015). 25 Januari, Hari Gizi Nasional. [Online]. Diakses dari: http://www. depkes.go.id/pdf.php?id=15012300021 (3 Juni 2018).

Departemen Kesehatan. (2017). Bayi Gendut, Lucu Tapi Belum Tentu Sehat. [Online]. Diakses dari: http:// www.depkes.go.id/article/print/17012300002/ bayi-gendut-lucu-tapi-belum-tentu-sehat.html (3 Juni 2018).

Diener, E., Wirtz, D., Biswas-diener, R., Tov, W.,
Kim-prieto, C., Choi, D., \& Oishi, S. (2009). New Measures of Well-Being. https://doi. org/10.1007/978-90-481-2354-4

Dinas Kesehatan Provinsi Jawa Barat. (2016). Profil Kesehatan Jawa Barat 2016.

DiPietro, R. B., Remar, D., \& Parsa, H. G. (2016). Health consciousness, menu information, and consumers' purchase intentions: An empirical investigation. Journal of Foodservice Business Research, 19(5), 497-513.

Fishbein, M., \& Ajzen, I. (1975). Belief, Attitude, Intention and Behaviour. London.

Garcia, D., Archer, T., Moradi, S., \& Andersson-Arntén, A.-C. (2012). Exercise Frequency, High Activation Positive Affect, and Psychological Well-Being: BeyondAge, Gender, and Occupation. Psychology, 3(4), 328-336.

Garcia, D., Jimmefors, A., Mousavi, F., Adrianson, L., Rosenberg, P., \& Archer, T. (2015). Self-regulatory mode (locomotion and assessment), well-being (subjective and psychological), and exercise behavior (frequency and intensity) in relation to high school pupils' academic achievement. PeerJ, 3, e847. https://doi.org/10.7717/peerj.847

Gayatri, D. (2004). Mendesain instrumen pengukuran sikap, 8(2), 76-80.

Gillison, F. B., Standage, M., \& Skevington, S. M. (2006). Relationships among adolescents 'weight perceptions, exercise goals, exercise motivation, quality of life and leisure-time exercise behaviour : a self-determination theory approach, 21(6), 836847. https://doi.org/10.1093/her/cyl139

Giriwijoyo, S., \& Sidik, Z.. Ilmu Kesehatan Olahraga. Bandung: PT Remaja Rosdakarya.

Hong, H. (2009). Scale Development for Measuring Health Consciousness: Re-conceptualization. 12th Annual International Public Relations Research Conference. https://doi.org/10.1016/j. pubrev.2009.01.003

Jose, P. E. (2013). Doing Statistical Mediation and Moderation. London: The Guilford Press.

Karn, S., \& Swain, S. K. (2017). Health consciousness through wellness tourism :a new dimension to new age $t$ ravelers '. African Journal of Hospitality, Tourism and Leisure, 6(3), 1-9.

Kenyon, G. (1968). Six scales for assessing attitude toward physical activity. Research Quarterly, 39(3),

Maghvira, G. (2016). Implementasi Konsep Diri pada Kelompok Gemes (Gemuk Menawan Semarang). Jurnal Ilmiah Komunika, 6(2), 1-14.

Nurcahyo, F. (2011). Kaitan Antara Obesitas dan Aktivitas Fisik. Medikora, 7(1), 87-96.

Obesity Working Group. (2011). Obesity in the UK : A psychological perspective Obesity Working Group 2011.

Pelletier, L. G., Rocchi, M. A., Vallerand, R. J., Deci, E. 
L., \& Ryan, R. M. (2013). Validation of the revised sport motivation scale ( SMS-II ). Psychology of Sport \& Exercise, 14(3), 329-341. https://doi. org/10.1016/j.psychsport.2012.12.002

Pemprov Jawa Barat. (2013). Konsep Awal Pengembangan Metropolitan Bandung Raya. https://doi. org/10.1017/CBO9781107415324.004

Pethkar, V., Naik, S., \& Sonawane, S. (2010). Attitudes toward physical activity and its measurement, (December).

Purwandari, H. (2014). Hubungan Obesitas dengan Kadar Gula Darah pada Karyawan Di Rs Tingkat IV, 1, 65-72.

Rondonuwu, R. G., Rompas, S., \& Bataha, Y. (2016). Hubungan antara Perilaku Olahraga dengan Kadar Gula Darah Penderita Diabetes Mellitus di Wilayah Kerja Puskesmas Wolaang Kecamatan Langowan Timur. Ejournal Keperawatan, 4(1), 1-7.

Rowland, L., Dickinson, E. J., Newman, P., Ford, D., \& Ebrahim, S. (1994). Look After Your Heart programme : impact on health status, exercise knowledge, attitudes, and behaviour of retired women in England, 123-128.

Rusmanto. (2013). Faktor-Faktor yang Mempengaruhi Sikap dan Perilaku Masyarakat Terhadap Kepatuhan Minum Obat Anti Filaria di RW II Kelurahan Pondok Aren. Universitas Islam Negeri Syarif Hidayatullah.

Ryff, C. D., \& Keyes, C. L. M. (1995). The Structure of Psychological Well-Being Revisited, 69(4), 719727.

Ryff, C. D., \& Singer, B. (1996). Psychological wellbeing: meaning, measurement, and implications for psychotherapy research. Psychother Psychom, 65, 14-23. https://doi.org/10.1159/000289026

Ryff, C. D., \& Singer, B. (1996). Psychological wellbeing: meaning, measurement, and implications for psychotherapy research. Psychother Psychom, 65, 14-23. https://doi.org/10.1159/000289026

Ryff, C. D. (2013). Psychological well-being revisited: Advances in the science and practice of eudaimonia. Psychotherapy and Psychosomatics, 83(1), 10-28. https://doi.org/10.1159/000353263

Ryff, C. D., \& Singer, B. H. (2013). The Exploration of Happiness.

Sajawandi, L. (2013). Pengaruh Obesitas pada Perkembangan Siswa Sekolah Dasar dan Penanganannya dari Pihak Sekolah dan Keluarga.
Universitas Muhammadiyah Purwokerto.

Sallis, J. F., \& Hovell, M. F. (1990). Determinants of Exercise. Exercise and Sport Sciences Reviews. https://doi.org/10.1249/00003677-19900100000014

Shepherd, D., Krägeloh, C., Ryan, C., \& Schofield, G. (2012). Psychological Well-Being, Self-Reported Physical Activity Levels, and Attitudes to Physical Activity in a Sample of New Zealand Adolescent Females, 3(6), 447-453.

Tandayu, F. (2014). Pengaruh motivasi, pengetahuan serta tindakan olahraga terhadap tindakan konsumsi pangan pelaku fitness usia dewasa fernando tandayu. INSTITUT PERTANIAN BOGOR.

The GBD 2015 Obesity Collaborators. (2017). Health Effects of Overweight and Obesity in 195 Countries over 25 Years. The New England Journal of Medicine, 377(1), 13-27. https://doi. org/10.1056/NEJMoa1614362

Uzogara, S. G. (2017). Obesity Epidemic , Medical and Quality of Life Consequences: A Review, 5(1), $1-12$.

Vallerand, R. J. (1997). Toward a hierarchical model of intrinsic and extrinsic motivation. Advances in Experimental Social Psychology, 29, 271-360. https://doi.org/10.1016/S0065-2601(08)60019-2

Vanvoorhis, C. R. W., \& Morgan, B. L. (2007). Understanding Power and Rules of Thumb for Determining Sample Sizes, 3(2).

Venhoven, R. (2006). How Do We Asses How Happy We Are? Tenets, Implications, and Tenability of Three Theories. New Directions in The Study of Happiness: United State and International Perspectives, 6.

Weiss, L. A., Westerhof, G. J., \& Bohlmeijer, E. T. (2016). Can we increase psychological well-being? The effects of interventions on psychological wellbeing: A meta-analysis of randomized controlled trials. PLoS ONE, 11(6), 1-16. https://doi. org/10.1371/journal.pone.0158092

Wood, M., \& Shukla, P. (2016). Weight bias, health consciousness and behavioral actions (activities). Eating Behaviors, 23, 200-205.

World Health Organization (WHO). (2017). Obesity and Overweight. [Online]. Diakses dari: http://www. who.int/news-room/fact-sheets/detail/obesity-andoverweight (2 Juni 2018). 